Ekonomia - Wroclaw Economic Review 24/1 (2018)

Acta Universitatis Wratislaviensis

No 3832

DOI: 10.19195/2084-4093.24.1.2

Tadeusz Białek

Związek Banków Polskich

Zespół Prawno-Legislacyjny

tadeusz.bialek@zbp.pl

Joanna Niska

Związek Banków Polskich

Zespół Prawno-Legislacyjny

joanna.niska@cpb.pl

\title{
Prawne aspekty udzielania kredytów denominowanych oraz indeksowanych do waluty obcej
}

Artykuł nadesłany: 12 listopada 2017 r.; artykuł zaakceptowany: 28 listopada 2017 r.

JEL Classification: G2, G20, G21, G28, G29

Keywords: mortgage loans, foreign currencies, Swiss francs, Banking Law, bank, spread

\begin{abstract}
Legal aspects of granting loans denominated and indexed in a foreign currency

This study addresses the issue of the legality of the denominated and indexed loans in a foreign currency under the current applicable law, with reference to the existing position of doctrine and case law in this area. The starting point for this considerations is the arbitrarily accepted thesis in the public discourse that the credit agreements denominated and indexed in a foreign currency were defective due to their lack of compliance with the applicable law or because their included the provisions that were unfair market practices. This study is an attempt to dispel doubts to the compliance of the loan granting mechanism with the commonly applicable laws in Poland, in particular with the provision of Article 69 of the Banking Law, setting forth the rules of concluding by the bank the credit agreement with the borrowers or a provision of Article $358^{1} \S 2$ of the Civil Code providing for the possibility of using so-called valorization clauses. This study also delivers opinion of the National Bank of Poland or the Financial Supervision Commission, which very often are deliberately omitted or distorted in the public discourse.
\end{abstract}




\section{Wstęp}

W publicznym dyskursie niejednokrotnie pobrzmiewają głosy, że w latach 20052008 udzielano kredytów denominowanych oraz indeksowanych do waluty obcej (zwłaszcza we franku szwajcarskim) pomimo istotnych wątpliwości co do zgodności ich mechanizmu z przepisami prawa. Warto jednak zauważyć, że wątpliwości te pojawiły się dopiero w ostatnich latach. Największy wpływ na formowanie się tego mitu miała zapewne zmiana kursu walut, w szczególności ogłoszona 15 stycznia 2015 roku decyzja Szwajcarskiego Banku Narodowego (niem. Schweizerische Nationalbank/ang. Swiss National Bank - SNB) o porzuceniu polityki obrony minimalnego kursu wymiany euro na franka szwajcarskiego. Podczas konferencji prasowej Prezes Zarządu SNB - Thomas J. Jordan - poinformował, że usztywnienie kursu zostało wprowadzone w okresie znaczącego przewartościowania franka szwajcarskiego i miało charakter tymczasowy. W oficjalnym komunikacie prasowym podano ponadto, że utrzymywanie minimalnego kursu wymiany franka szwajcarskiego względem euro nie jest już uzasadnione $z$ uwagi na znaczące osłabienie euro wobec dolara amerykańskiego, co z kolei przełożyło się na osłabienie franka szwajcarskiego względem dolara ${ }^{1}$.

Okoliczność tę słusznie dostrzegają sądy w uzasadnieniach wydawanych wyroków. Sąd Apelacyjny w Białymstoku w wyroku z dnia 20 listopada 2012 roku orzekł:

Tabele kursów walut stosowane przez banki w latach ubiegłych do kredytów denominowanych do walut obcych nie były przez kredytobiorców kwestionowane dopóty, dopóki kurs waluty polskiej do głównych walut, w których udzielono kredytów lub do których kredyt ten był denominowany (USD, EUR), był stabilny².

Jednocześnie Urząd Komisji Nadzoru Finansowego w raporcie pod tytułem Ocena wplywu na sytuacje sektora bankowego i polskiej gospodarki propozycji przewalutowania kredytów mieszkaniowych udzielonych w CHF na PLN wedtug kursu z dnia udzielenia kredytu wskazuje, iż

[w]brew pojawiającym się opiniom banki nie są beneficjentami osłabienia PLN względem CHF. Wynika to z tego, że wraz z osłabieniem złotego rosły nie tylko należności banków (z tytułu udzielonych kredytów CHF), ale równolegle rosły ich zobowiązania wobec deponentów i kontrahentów transakcji zawieranych w celu finansowania portfela kredytów CHF. W kontekście wygłaszanych obecnie opinii i propozycji trzeba też stwierdzić, że większość banków prowadziła konserwatywną politykę w zakresie kredytów walutowych dla gospodarstw domowych (część z nich w ogóle nie udzielała tych kredytów i opowiadała się za ich wyeliminowaniem). Jednocześnie w latach 2005-

1 Zob. Schweizerische Nationalbank, Press release: Swiss National Bank discontinues minimum exchange rate and lowers interest rate to $-0.75 \%, 15.01 .2015$, https://www.snb.ch/en/mmr/ reference/pre_20150115/source/pre_20150115.en.pdf (dostęp: 21.11.2017).

2 Wyrok Sądu Apelacyjnego w Białymstoku z dnia 20 listopada 2012 roku, I ACa 499/12, LEX nr 1235971. 
2008 na KNB/KNF oraz banki była wywierana silna presja w celu zwiększenia kredytowania gospodarstw domowych w walutach obcych, jak też zniesienia wszelkich ograniczeń w tym zakresie ${ }^{3}$.

Zgodnie z uproszczonymi wyliczeniami podanymi przez Urząd Komisji Nadzoru Finansowego,

gdyby przyjąć, że bank udzielił kredytów CHF o wartości 1,0 mld zł po kursie 2,0 zł w oparciu o przyjęte depozyty CHF, również o wartości 1,0 mld zł, to w rezultacie wzrostu kursu CHF/PLN z 2,0 na 3,0 nastąpiłby wzrost wartości należności do $1,5 \mathrm{mld}$ zł, któremu towarzyszyłby wzrost zobowiązań również do 1,5 mld zł (gdyby bank finansował akcję kredytową w inny sposób, to wzrostowi należności towarzyszyłby wzrost innych zobowiązań wynikających z transakcji zawartych na rynku finansowym w celu możliwości udzielenia kredytów oraz konieczności zamknięcia otwartej pozycji walutowej). Gdyby dokonać przewalutowania kredytów CHF na PLN po kursie z dnia udzielenia kredytu, to doszłoby do sytuacji, w której zmniejszeniu uległyby należności banków (czyli zobowiązania kredytobiorców), ale zobowiązania banków nie uległyby zmianie. W konsekwencji banki musiałyby odnotować bardzo wysokie straty finansowe ${ }^{4}$.

Obecnie, gdy doszło do zmian kursów walut, odpowiedzialnością za zaistniałą sytuację niesłusznie obciążane są banki. Komentatorzy z reguły pomijają fakt, iż narastający wzrost popularności kredytów we franku szwajcarskim od 2004 roku stał się przyczyną zainicjowania publicznej dyskusji (między innymi przez Związek Banków Polskich) dotyczącej ograniczenia bądź zakazania udzielania kredytów w walucie obcej ${ }^{5}$.

1 lipca 2006 roku Komisja Nadzoru Bankowego ${ }^{6}$ wydała $^{7}$ na podstawie art. 137 pkt 5 ustawy Prawo bankowe dokument zatytułowany Rekomendacja $S$

3 Urząd Komisji Nadzoru Finansowego, Ocena wpływu na sytuację sektora bankowego i polskiej gospodarki propozycji przewalutowania kredytów mieszkaniowych udzielonych w CHF na PLN wedlug kursu z dnia udzielenia kredytu, Warszawa 2013, s. 4, https://www.knf.gov.pl/?articleId=56126\&p_ id=18 (dostęp: 8.11.2017).

4 Ibidem, s. 8 .

5 Komisja Nadzoru Finansowego, Przypomnienie publicznej dyskusji o kredytach walutowych, 10.03.2015, https://www.knf.gov.pl/knf/pl/komponenty/img/knf_130218_przypomnienie_publicznej_dyskusji_CHF_40728.pdf(dostęp: 21.11.2017).

${ }^{6}$ Komisja Nadzoru Bankowego została zniesiona 31 grudnia 2007 roku, a jej zadania od 1 stycznia 2008 roku na podstawie art. 66 i art. 67 ust. 2 Ustawy z dnia 21 lipca 2006 roku o nadzorze nad rynkiem finansowym (Dz.U. z 2006 r. Nr 157, poz. 1119 z późn. zm.) przejęła Komisja Nadzoru Finansowego.

${ }^{7}$ Komisja Nadzoru Finansowego wydaje rekomendacje dotyczące dobrych praktyk ostrożnego i stabilnego zarządzania bankami na podstawie art. 137 Ustawy z dnia 29 sierpnia 1997 roku — Prawo bankowe (tekst jedn. Dz.U. z 2016 r. poz. 1988 z późn. zm.). W doktrynie wskazuje się, że rekomendacje KNF należą do nienormatywnych form działania administracji. Zdaniem Tomasza Czecha „wydane przez KNF rekomendacje — podobnie jak inne uchwały organu nadzoru — nie są źródłem ani powszechnie obowiązujących przepisów prawa, ani przepisów o charakterze wewnętrznym. Banki nie są jednostkami organizacyjnie podległymi KNF w rozumieniu art. 93 ust. 1 Konstytucji”. Zdaniem tego autora „KNF nie dysponuje kompetencją, żeby w sposób prawnie wiążący - czy to w formie zalecenia, czy innego rodzaju jednostronnego rozstrzygnięcia władczego — zobowiązać bank do przestrzegania wskazówek, jakie wynikają z wydanych uprzednio rekomendacji” — idem, Charakter prawny rekomendacji Komisji Nadzoru Finansowego, „Przegląd Prawa Publicznego" 2009, nr 11, s. 63. Podobny pogląd był wyrażany także przed wprowadzeniem upo- 
dotyczaca dobrych praktyk $w$ zakresie ekspozycji kredytowych zabezpieczonych hipotecznie ${ }^{8}$. Wprowadzono tym samym obostrzenia polegające na ograniczeniu dostępu do kredytów w walutach obcych ${ }^{9}$. Warto podkreślić, że banki współpracowały przy wprowadzaniu rekomendacji oraz ją popierały, podczas gdy otoczenie żądało natychmiastowego jej wycofania ${ }^{10}$. Tytułem przykładu wystarczy wskazać, że Premier RP Kazimierz Marcinkiewicz 1 lipca 2006 roku podczas briefingu prasowego między innymi w sprawie kredytów we frankach stwierdził, iż „,[n]ie rozumie polityki utrudniania dostępu do kredytów i nie zgadza się z nią". Ponadto Urząd Ochrony Konkurencji i Konsumentów w oficjalnym piśmie skierowanym do Związku Banków Polskich z sierpnia 2006 roku podkreślił, że „wprowadzenie ograniczeń w udzielaniu kredytów walutowych jest rozwiązaniem zbyt daleko idącym”. Wskazywał także na rolę banku, który „na podstawie już obowiązujących przepisów - powinien zapewnić konsumentowi rzetelną i pełną informację na temat zagrożeń i przysługujących im praw". Jednak ostateczna decyzja, jaki rodzaj kredytu wybrać, bezwzględnie powinna należeć do klienta ${ }^{11}$.

Z kolei Prezes Urzędu Ochrony Konkurencji i Konsumentów w odpowiedzi na pismo portalu Money.pl w kontekście wydanej przez Komisję Nadzoru

ważnienia do wydawania rekomendacji do regulacji ustawowych dotyczących nadzoru bankowego, zawartych w ustawie Prawo bankowe. Zdaniem Janusza A. Krzyżewskiego należało je „traktować jako akty o cechach dydaktyki oficjalnej, kreującej modele działania banków wobec konkretnych typów ryzyk, bo służą prawidłowej ocenie i dotyczą prawidłowego zabezpieczenia przed konkretnymi ryzykami" - idem, Rekomendacje nadzorcze - charakter prawny i zakres mocy obowiazujacej, „Prawo Bankowe” 2000, nr 7-8, s. 111-121. Zob. też E. Rutkowska, Środki nadzoru bankowego, [w:] Prawo bankowe, red. E. Fojcik-Mastalska, Wrocław 2009, s. 157-162.

${ }^{8}$ Komisja Nadzoru Bankowego, Rekomendacja S dotyczaca dobrych praktykwzakresie ekspozycji kredytowych zabezpieczonych hipotecznie, Warszawa 2006, https://www.knf.gov.pl/dla_rynku/ regulacje_i_praktyka/rekomendacje_i_wytyczne/rekomendacje_dla_bankow?articleId=8576\&p_ id=18 (dostęp: 21.11.2017).

9 Jednym z zaleceń Komisji Nadzoru Bankowego było to, aby banki w pierwszej kolejności oferowały klientom kredyty, pożyczki lub inne produkty w złotych. Zgodnie z rekomendacją 19 (pkt 5.1.5) bank może złożyć klientowi ofertę kredytu, pożyczki lub innego produktu w walucie obcej lub indeksowanego do waluty obcej dopiero po uzyskaniu od klienta banku pisemnego oświadczenia potwierdzającego, że dokonał on wyboru oferty w walucie obcej lub indeksowanej do waluty obcej, mając pełną świadomość ryzyka związanego z kredytami, pożyczkami i innymi produktami zaciąganymi w walucie obcej lub indeksowanymi do waluty obcej.

${ }^{10}$ Należy wskazać choćby na stanowisko wyrażane przez polityków: „Klub Parlamentarny Prawo i Sprawiedliwość z niepokojem przyjmuje zalecenia Komisji Nadzoru Bankowego, tzw. »Rekomendację S«, wprowadzające ograniczenia w dostępności do kredytów walutowych, których głównym skutkiem będzie zmniejszenie możliwości nabywania przez obywateli (szczególnie przez młode osoby) własnych mieszkań”. Co do przekazywanych ostrzeżeń dotyczących ryzyka w komunikacie prasowym Klubu Parlamentarnego PiS wskazano, że z uwagi na „ciągły wzrost gospodarczy naszego kraju, niską inflację i umacniającą się złotówkę” należy dojść do wniosku, że obawy „nie znajdują potwierdzenia w faktach" — http://old.pis.org.pl/article.php?id=4415 (dostęp: 8.11.2017).

11 Związek Banków Polskich, Biała księga kredytów frankowych w Polsce, Warszawa 2015, s. 4-5, 56, https://zbp.pl/public/repozytorium/wydarzenia/images/marzec_2015/BIAA_OST_2_4_ marca_2015_small_.pdf (dostęp: 8.11.2017). 
Bankowego Rekomendacji $S$ przedstawił pogląd, iż dostrzegane jest zagrożenie, ,jakie niesie ograniczenie możliwości udzielania kredytów walutowych, dla konkurencji w sektorze bankowym w segmencie kredytów hipotecznych"12, a nowe regulacje mogą utrudniać działalność kredytową bankom udzielającym kredytów walutowych. Nawiązując do tego niebezpieczeństwa, ponownie stwierdzono w niej, że „wprowadzenie ograniczeń w udzielaniu kredytów walutowych jest rozwiązaniem zbyt daleko idącym, a ostateczna decyzja, jaki rodzaj kredytu wybrać, zawsze powinna należeć do konsumenta"13.

Zaprezentowane kwestie zostały, wraz z odesłaniem do źródeł, szczegółowo przedstawione w opracowaniu Biała księga kredytów frankowych w Polsce, opublikowanym w marcu 2015 roku $^{14}$.

\section{Dopuszczalność klauzul walutowych w świetle art. 69 ust. 2 pkt 2 i pkt $4 a$ oraz ust. 3 Prawa bankowego}

Poruszając kwestię dopuszczalności udzielania kredytów denominowanych oraz indeksowanych do waluty obcej, nie sposób pominąc najważniejszej regulacji określającej zasady prowadzenia działalności bankowej, jaką jest Ustawa z dnia 29 sierpnia 1997 roku — Prawo bankowe. Udzielenie kredytów to niewątpliwe podstawowa działalność banku (art. 5 ust. 1 pkt 3). W Polsce kredyty hipoteczne mogą być udzielane przez bank zarówno w złotych, jak i walucie obcej ${ }^{15}$. Najczęściej jednak kredyty bankowe udzielane są w walucie polskiej, jednakże pod pewnymi warunkami mogą być udzielane również jako kredyty nominowane w walutach obcych (na przykład euro, frankach szwajcarskich czy dolarach amerykańskich). Oznacza to, że kwota kredytu jest wyrażona w walucie obcej, natomiast przekazanie środków i ich spłata następuje w walucie polskiej z zastosowaniem właściwego kursu walutowego ${ }^{16}$. Taki wniosek wypływa bezpośrednio z redakcji art. 69 ust. 2 pkt 2 przywołanej ustawy, który wprowadza obowiązek zamieszczenia $\mathrm{w}$ treści umowy o kredyt obligatoryjnego postanowienia dotyczącego określenia kwoty oraz waluty kredytu. Wymóg ten został ukształtowany już

12 Prezes Urzędu Ochrony Konkurencji i Konsumenta, Odpowiedź z dnia 2 sierpnia 2006 r. na pismo Redaktora Naczelnego money.pl (DDK-076-251/06/KB), s. 1, https://www.google.pl/url?sa$=\mathrm{t} \& \mathrm{rct}=\mathrm{j} \& \mathrm{q}=\& \mathrm{esrc}=\mathrm{s} \&$ source $=$ web\&cd $=2 \& \mathrm{cad}=\mathrm{rja} \& u a c t=8 \& \mathrm{ved}=0 \mathrm{ahUKEwijt}$ DPyc_XAhUmJJ oKHeD8BfsQFggtMAE\&url=http\%3A\%2F\%2Fwww.money.pl\%2Fu\%2Ffile.php\%3Fid\%3D3477 \&usg=AOvVaw1qj0KOdYLCwCK0qNKoS1yi (dostęp: 21.11.2017).

13 Ibidem.

14 https://zbp.pl/public/repozytorium/wydarzenia/images/marzec_2015/BIAA_OST_2_4 marca_2015_small_pdf(dostęp: 8.11.2017).

15 Szerzej zob. Prawo bankowe. Komentarz, red. G. Sikorski, Warszawa 2015.

16 Z. Ofiarski, Prawo bankowe. Komentarz, Warszawa 2013, s. 489. 
w pierwotnym tekście Ustawy z dnia 29 sierpnia 1997 roku — Prawo bankowe, która weszła w życie 1 stycznia 1998 roku. W literaturze przedmiotu wskazuje się, że

zawarte w treści w art. 69 ust. 2 pkt 2 Prawa bankowego określenie „waluta kredytu” (w tym również waluta, w której następuje przeliczenie środków kredytowych rzeczywiście wypłacanych kredytobiorcy) powinno być rozumiane szeroko, tzn. kwota kredytu może być wyrażona zarówno w walucie polskiej, jak i w walucie obcej (także w celu dokonywania przeliczenia środków kredytowych udostępnianych kredytobiorcy). Określenie waluty kredytu stanowi przy tym niezbędny element treści umowy o kredyt ${ }^{17}$.

Dodatkowo 26 sierpnia 2011 roku weszła w życie nowelizacja ustawy Prawo bankowe dokonana Ustawą z dnia 29 lipca 2011 roku o zmianie ustawy Prawo bankowe oraz niektórych innych ustaw ${ }^{18}$ (tak zwana ustawa antyspreadowa), która wprowadziła do polskiego porządku prawnego art. 69 ust. 2 pkt 4 a oraz ust. 3 ustawy Prawo bankowe.

Pierwszym obszarem wprowadzonych zmian było przyznanie kredytobiorcom prawa do spłaty rat kapitałowo-odsetkowych oraz spłaty przedterminowej pełnej lub częściowej kwoty kredytu bezpośrednio w tej walucie. W celu umożliwienia kredytobiorcy takiego działania banki zobowiązane są do określenia w umowie kredytu zasad otwarcia i prowadzenia rachunku służącego do gromadzenia środków przeznaczonych na spłatę kredytu oraz zasad dokonywania spłaty za pośrednictwem tego rachunku (art. 69 ust. 3), jednocześnie bank nie może uzależnić wykonania przez kredytobiorcę tego uprawnienia od wprowadzenia dodatkowych ograniczeń, w szczególności nie może zobowiązać kredytobiorcy do nabywania waluty przeznaczonej na spłatę rat kredytu, jego całości lub części od określonego podmiotu (art. 75b ust. 2 ustawy Prawo bankowe).

Podobne rozwiązanie wprowadziła Rekomendacja $T$ dotycząca dobrych praktyk w zakresie zarządzania ryzykiem detalicznych ekspozycji kredytowych, wydana przez Komisję Nadzoru Finansowego w lutym 2010 roku, zgodnie z którą w wypadku kredytu indeksowanego kursem waluty obcej bank powinien, na życzenie klienta, zagwarantować w umowie spłatę kredytu w walucie, do jakiej kredyt jest indeksowany, bez obowiązku ponoszenia kosztów, które mogłyby utrudniać klientowi skorzystanie z takiej możliwości (rekomendacja 24.4) ${ }^{19}$.

17 Z. Ofiarski, Z. Kuniewicz, Problem dopuszczalności przekształcenia kredytu denominowanego lub indeksowanego do waluty obcej w kredyt w walucie polskiej z uwagi na abuzywność klauzuli walutowej (uwagi na tle art. 69 PrBank do art. 3851 \& KC), [w:] Życie umowy konsumenckiej po uznaniu jej postanowienia za nieuczciwe na tle orzecznictwa Trybunatu Sprawiedliwości, red. M. Romanowski, Warszawa 2017, s. 250.

18 Dz.U. Nr 165, poz. 984, druk sejmowy nr 4413 Sejmu RP VI kadencji, http://orka.sejm.gov. pl/proc6.nsf/opisy/4413.htm (dostęp: 8.11.2017).

${ }^{19}$ Komisja Nadzoru Finansowego, Rekomendacja T dotyczaca dobrych praktyk $w$ zakresie zarzadzania ryzykiem detalicznych ekspozycji kredytowych, Warszawa 2010, https://www. knf.gov.pl/dla_rynku/regulacje_i_praktyka/rekomendacje_i_wytyczne/rekomendacje_dla_ bankow?articleId=8576\&p_id=18 (dostęp: 21.11 .2017$)$. 
Zmiana ta oznacza jednocześnie umożliwienie z mocy prawa dokonywania spłaty kredytu w walucie indeksacyjnej ${ }^{20}$.

Druga ze zmian wprowadziła obowiązek informacyjny wobec kredytobiorców poprzez zawarcie w umowie kredytu zasad określania sposobów i terminów ustalania kursu wymiany walut, na podstawie którego w szczególności wyliczana jest kwota kredytu, jego transz i rat kapitałowo-odsetkowych oraz zasad przeliczania na walutę wypłaty albo spłaty kredytu (art. 69 ust. 2 pkt 4a). Dotychczas w art. 69 ust. 2 nie było wskazane, że banki powinny zawierać w umowie kredytowej szczegółowe zasady dotyczące określenia sposobów i terminów ustalania kursu wymiany walut, na podstawie którego w szczególności wyliczana jest kwota uruchamianego kredytu, jego transz i rat kapitałowo-odsetkowych oraz zasad przeliczania na walutę wypłaty i spłaty kredytu ${ }^{21}$. Zgodnie z intencją ustawodawcy dzięki temu rozwiązaniu banki będą konkurowały między sobą wysokością tak zwanego spreadu. $\mathrm{W}$ odniesieniu bowiem do kredytów denominowanych lub indeksowanych w innej walucie niż polska oprócz kosztu odsetkowego kredytobiorca ponosi koszty zmian kursowych i kursów walut przyjętych w danym banku (tak zwany spread walutowy). Koszty te muszą być znane dłużnikowi w momencie zawierania umowy ${ }^{22}$. Jak wskazuje się w literaturze przedmiotu, brzmienie pkt 4a nie nakłada de facto na banki żadnych nowych obowiązków ani nie określa wprost, jak dokładnie, a przede wszystkim w jaki sposób powinien być zdefiniowany w umowie sposób i termin ustalania kursów wymiany walut. Większość polskich banków posiada w umowach kredytowych właściwe postanowienia regulujące tę kwestię 23 .

Wprowadzenie tych przepisów przywołaną nowelizacją z 2011 roku nie oznacza jednak, że zawieranie umów o kredyt denominowany oraz indeksowany do waluty obcej nie było wcześniej dopuszczalne. Do takiej konstatacji skłania (jak już wskazano) ogólna konstrukcja kredytu bankowego, z której wynika, iż obligatoryjny element każdej umowy kredytowej, jakim jest określenie w jej treści ,waluty kredytu" (art. 69 ust. 2 pkt 2), należy interpretować szeroko, a więc jako kwotę kredytu wyrażoną zarówno w walucie polskiej, jak i obcej. Co więcej, podstaw prawnych dostarcza również ogólna zasada swobody umów wyrażona w art. $353^{1}$ k.c., zgodnie z którą strony zawierające umowę mogą ułożyć stosunek prawny według swego uznania, byleby jego treść lub cel nie sprzeciwiały się właściwości (naturze) stosunku, ustawie ani zasadom współżycia społecznego ${ }^{24}$. W podobnym tonie wy-

20 Uzasadnienie do poselskiego projektu ustawy z dnia 1 lipca 2011 roku o zmianie ustawy Prawo bankowe, druk sejmowy nr 4413 Sejmu RP VI kadencji, http://orka.sejm.gov.pl/proc6.nsf/ opisy/4413.htm (dostęp: 8.11.2017).

21 Ibidem.

22 Por. T. Czech, Splata kredytu udzielonego $w$ walucie obcej lub indeksowanego do waluty obcej, „Monitor Prawa Bankowego” 2011, nr 11, s. 63-79, cyt. za: Prawo bankowe. Komentarz, red. G. Sikorski, Legalis.

23 B. Paxford, Kredyty i pożyczki pieniężne oraz zasady koncentracji zaangażowań, [w:] Prawo bankowe. Komentarz, red. H. Gronkiewicz-Waltz, Warszawa 2013, s. 239-253.

24 Z. Ofiarski, M. Kuniewicz, op. cit., s. 268. 
powiedział się Sąd Najwyższy w wyroku z dnia 22 stycznia 2016 roku, stwierdzając, iż ,umowa kredytu indeksowanego, zawarta przed nowelizacją art. 69 Prawa bankowego z 2011 r., mieści się w konstrukcji ogólnej umowy kredytu bankowego i stanowi jej możliwy wariant w ramach art. $353^{1}$ k.c." ${ }^{25}$.

Ratio legis wprowadzonych przepisów była ochrona kredytobiorcy (konsumenta) przed zmianami wysokości rat kredytu (denominowanego w walucie obcej lub indeksowanego do waluty obcej), które mogłyby niekorzystnie wpłynąć na możliwość spłaty kredytu przez kredytobiorcę ${ }^{26}$, a także umożliwienie i ułatwienie dokonywania spłaty rat kapitałowo-odsetkowych w walucie indeksacyjnej. Przede wszystkim chodziło o to, aby bank obowiązkowo umieszczał w umowie kredytowej informację o możliwości dokonywania spłaty w walucie indeksacyjnej ${ }^{27}$. W doktrynie podnosi się również, iż przytoczone przepisy stanowią także reakcję ustawodawcy na stosowanie przez banki tak zwanego spreadu, czyli różnicy pomiędzy kosztem kupna i sprzedaży waluty ustalanym przez bank ${ }^{28}$.

Zasadniczo jednak omawianą nowelizację ocenia się pozytywnie, ponieważ umożliwia ona i ułatwia dokonywanie spłaty rat kapitałowo-odsetkowych w walucie indeksacyjnej. Najistotniejsza zmiana polega natomiast na nałożeniu na bank obowiązku umieszczania w umowie kredytu informacji o możliwości dokonywania spłaty w walucie indeksacyjnej, w związku z czym kredytobiorcy nie muszą za tego typu postanowienia umowne uiszczać dodatkowych wysokich opłat z powodu sporządzanych aneksów do umów kredytu ${ }^{29}$.

Przepisy intertemporalne związane ze stosowaniem nowelizacji Prawa bankowego oddalają również wątpliwości co do tego, czy zawieranie kredytów denominowanych i indeksowanych do waluty obcej było prawnie dopuszczalne przed dniem jej wejścia w życie ${ }^{30}$. Mianowicie, zgodnie art. 4 tej ustawy, w wypadku kredytów lub pożyczek pieniężnych zaciągniętych przez kredytobiorcę lub pożyczkobiorcę przed dniem wejścia w życie niniejszej ustawy zastosowanie ma art. 69 ust. 2 pkt $4 \mathrm{a}$ oraz art. 75b ustawy, o której mowa w art. 1, w stosunku do tych kredytów lub pożyczek pieniężnych, które nie zostały całkowicie spłacone — do tej części kredytu lub pożyczki, która pozostała do spłacenia. W tym zakresie bank dokonuje bezpłatnie stosownej zmiany umowy kredytowej lub umowy pożyczki. Jak wskazuje projektodawca w uzasadnieniu,

proponuje się, aby rozwiązania przewidziane w projekcie miały zastosowanie nie tylko do umów nowo zawieranych, ale również do umów o kredyt zabezpieczonych hipoteką, które zostały zawarte przed dniem wejścia w życie ustawy, lecz nie nastąpiła spłata pełnej kwoty kredytu. Oznacza to,

25 Por. też Wyrok Sądu Najwyższego z dnia 19 marca 2015 roku, IV CSK 362/14, LEX nr 1663827.

26 B. Paxford, op. cit., s. 261.

27 Druk sejmowy nr 4413 Sejmu RP VI kadencji.

28 A. Kawulski, Prawo bankowe. Komentarz, LEX 2013.

29 Z. Ofiarski, op. cit.

30 Ibidem, s. 493. 
że powyższe rozwiązanie zapewnia również wyrównanie sytuacji osób, które zawarły już umowy o walutowy kredyt zabezpieczony hipoteką [...] decydując się na dokonywanie jego spłaty bezpośrednio w walucie indeksacyjnej ${ }^{31}$.

W podobnym tonie wypowiedział się również projektodawca we wcześniejszej wersji uzasadnienia projektu ustawy nowelizującej, akcentując potrzebę rozwiązania problemu tak zwanych spreadów walutowych i

objęcia projektem dotychczasowych stosunków umownych z uwagi na konstytucyjne zasady sprawiedliwości społecznej, społecznej gospodarki rynkowej, ochrony rodziny, realizacji polityki sprzyjającej zaspokajaniu potrzeb mieszkaniowych obywateli oraz ochrony konsumentów przed niewłaściwymi praktykami, szczególnie w dowolnym kształtowaniu stosunku umownego, jakim jest umowa kredytowa $^{32}$.

Polski ustawodawca przy okazji nowelizacji ustawy Prawo bankowe nie zakwestionował więc legalności kredytów denominowanych i indeksowanych do walut obcych, tym samym poprzez wprowadzone zmiany niejako usankcjonował istniejący stan rzeczy, wzmacniając jednocześnie sytuację kredytobiorców.

Podobny pogląd wyraził Sąd Najwyższy w wyroku z dnia 19 marca 2015 roku:

Ideą dokonania nowelizacji prawa bankowego ustawą z dnia 29 lipca 2011 r. było utrzymanie funkcjonujących na rynku kredytów denominowanych według nowych zasad. [...] ustawodawca wprowadził narzędzie prawne pozwalające wyeliminować z obrotu postanowienia umowne zawierające niejasne reguły przeliczania należności kredytowych, zarówno na przyszłość [tj. w odniesieniu do zawieranych po wejściu w życie nowelizacji — T.B., J.N.], jak i w odniesieniu do wcześniej zawartych umów w części, która pozostała do spłacenia. Zatem abuzywność tych postanowień [...] została w powyższym zakresie usunięta. W takiej sytuacji, zgodnie ze stanowiskiem Sądu Najwyższego zawartym w cytowanym wyroku z dnia 23 października 2013 r., po stronie powodowej brak jest interesu prawnego w wytoczeniu powództwa ${ }^{33}$.

Jak wynika z zacytowanego wyroku, skutkiem wejścia w życie ustawy spreadowej jest brak interesu prawnego w wytoczeniu powództwa o ustalenie (art. 189 k.p.c.), że niedozwolone są postanowienia umowy o kredyt denominowany lub indeksowany do waluty innej niż waluta polska zawartej przed wejściem w życie ustawy z dnia 29 lipca 2011 roku.

Podobnie skonstatował Sąd Apelacyjny w Białymstoku w wyroku z dnia 20 listopada 2012 roku:

Niezależnie zatem od wpisania do rejestru klauzuli niedozwolonej pod pozycją $3178 \mathrm{w}$ stosunku do Banku [...] już przepisy analizowanej ustawy z 29 lipca $2011 \mathrm{r}$. ingerowały wprost w umowę łączącą strony z chwilą wejścia w życie tej ustawy z dniem 26 sierpnia 2011 r. Od tego momentu

31 Por. druk sejmowy nr 4413 Sejmu RP VI kadencji.

32 Por. uzasadnienie projektu ustawy z dnia 1 lipca 2011 roku o zmianie ustawy Prawo bankowe, druk sejmowy nr 4381 Sejmu RP VI kadencji, http://orka.sejm.gov.pl/proc6.nsf/opisy/4381. htm (dostęp: 8.11.2017), a także uzasadnienie projektu ustawy o zmianie ustaw dotyczących kredytu konsumenckiego, druk sejmowy nr 4350 Sejmu RP VI kadencji, http:/orka.sejm.gov.pl/proc6.nsf/ opisy/4350.htm (dostęp: 8.11.2017).

33 Wyrok Sądu Najwyższego z dnia 19 marca 2015 roku, IV CSK 362/14, LEX nr 1663827. 
powodom względem banku co do niespłaconych jeszcze rat służyło roszczenie o stosowną zmianę umowy, aby czyniła ona zadość postanowieniom art. 69 ust.2 pkt 4a ustawy Prawo bankowe, tj. w sposób szczegółowy regulowała sposób i zasady określania kursu wymiany waluty, do której są denominowane raty kapitałowe - odsetkowe kredytu powodów. Gdyby bank nie chciał uczynić tego dobrowolnie, zgodnie z obowiązkiem nałożonym na niego w art. 4 zd. ustawy z 29 lipca 2011 r. mogli wystąpić ze stosownym roszczeniem. Jak wcześniej wspomniano, pozwany przesłał powodom po wejściu ustawy (już w toku niniejszej sprawy, po wpisaniu niedozwolonej klauzuli [...] w stosunku do M.) aneks $\mathrm{Nr}$ [...] (k. 172-174) zawierający zasady ustalania kursów walut. [...] Nie powinno zatem w świetle przepisów ustawy 29 lipca 2011 r. o zmianie ustawy — Prawo bankowe oraz niektórych innych ustaw budzić wątpliwości to, że nie zachodzi żadna niepewność co do zasad spłaty kredytu przez powodów od momentu wejścia w życie tej ustawy. Mogą oni albo zawrzeć z pozwanym aneks do umowy regulujący szczegółowo zasady przeliczania waluty, do której mają denominowany kredyt, albo spłacać wymagalne raty bezpośrednio w tej walucie nabytej na rynku. Brak interesu prawnego w wytoczeniu powództwa czyni zbędnym dalsze rozważania $[\ldots]^{34}$.

\section{Z kolei zgodnie z wyrokiem Sądu Okręgowego w Szczecinie z dnia 24 lutego 2016 roku}

[p]owyższa ustawa w istocie spowodowała, że stosowanie tabeli kursowej Banku udzielającego kredytu zależy od woli konsumenta. W rezultacie postanowienia umów nakazujące stosowanie takich tabel nie są dla konsumenta wiążące i tym samym nie naruszają rażąco jego interesów w rozumieniu art. $385^{1}$ k.c. ${ }^{35}$

Za okres przed 26 sierpnia 2011 roku można natomiast zdaniem orzecznictwa dokonać jedynie oceny prawidłowości zastosowanych przez bank kursów. Jak wskazuje bowiem Sąd Najwyższy w cytowanym już wyroku z dnia 19 marca 2015 roku,

[w] przypadku części kredytu, który został już spłacony przez powodów, sytuacja kształtuje się odmiennie. Rozwiązania wprowadzone nowelą nie obejmują bowiem spłaconych należności. Zauważyć jednak należy, że częściowa spłata kredytu odbyła się według konkretnych zasad. Powodowie dokonali spłaty przy zastosowaniu określonego sposobu przeliczeń. Nawet jeśli był on niejasny według treści zaskarżonych postanowień umownych, to z chwilą dokonania spłaty został skonkretyzowany. W rezultacie niedozwolony (abuzywny) charakter tych postanowień został wyeliminowany. Tym samym usunięty został stan niepewności, który mógłby usprawiedliwiać interes prawny powodów. Oczywiście zupełnie inną kwestią jest ocena zastosowanych przeliczników przy spłacie kredytu, np. ze względu na zastosowanie spreadu walutowego. Jednakże kwestia ta po pierwsze nie była objęta żądaniem pozwu. Po drugie — jak trafnie przyjął Sąd Apelacyjny — powinna być rozważana w sprawie z powództwa o świadczenie ${ }^{36}$.

Tak też uznał Sąd Okręgowy w Szczecinie w wyroku z dnia 24 lutego 2016 roku:

Z kolei w odniesieniu do rat spłaconych przez powoda przed wejściem w życie powyższej ustawy (tj. przed 26 sierpnia 2011 r.) spłata kredytu nastąpiła według konkretnych kursów ustalonych w tabeli kursowej przez pozwany Bank. Nawet gdyby przyjąć, że konstrukcja umowy w zakresie odsyłającym

34 Wyrok Sądu Apelacyjnego w Białymstoku z dnia 20 listopada 2012 roku, I ACa 499/12, LEX nr 1235971.

35 Wyrok Sądu Okręgowego w Szczecinie z dnia 24 lutego 2016 roku, I C 523/15, LEX nr 2244692.

36 Wyrok Sądu Najwyższego z dnia 19 marca 2015 roku. 
do tabeli kursowych Banku stwarzała potencjalnie duże zagrożenie dla interesów powoda, to z chwilą dokonania zapłaty wpływ na interesy powoda jako konsumenta został już skonkretyzowany. W takiej sytuacji powód powinien wykazać, że zastosowanie konkretnych tabel kursowych rażąco naruszyło jego interesy. Powód tego nie wykazał. W istocie nie mógł tego wykazać, ponieważ istota problemu nie leży w tabeli kursowej pozwanego Banku, ale w kursie złotego do franka ${ }^{37}$.

Kwestia ustalania spreadu i jego wysokości były wielokrotnie przedmiotem badania Komisji Nadzoru Finansowego i Urzędu Ochrony Konkurencji i Konsumentów. Zarówno Komisja Nadzoru Finansowego, jak i Urząd Ochrony Konkurencji i Konsumentów stwierdzili jednak, iż sama wysokość spreadu jest kwestią polityki cenowej konkretnego banku i nie ma mowy o tym, aby administracyjnie regulować jego wysokość. To, co w ich ocenie powinno podlegać regulacji, to kwestia zasad ustalania spreadu i pełnego informowania o nich klienta. Należy bowiem uznać, że spread jest specyficznym wynagrodzeniem banku i nie stanowi opłaty lub prowizji w rozumieniu art. 110 Prawa bankowego ${ }^{38}$. Jednocześnie w ocenie Komisji Nadzoru Finansowego

w pewnym stopniu ryzykowne są także arbitralne i generalne stwierdzenia m.in. o naruszeniach obowiązków informacyjnych banków, czy też o niewłaściwie (w sposób sprzeczny z prawem) określonym mechanizmie wyliczania spreadu (,klauzule indeksacyjne”) w każdej sytuacji — ta bowiem różniła się w przypadku poszczególnych umów i ewentualne naruszenia przepisów o zobowiązaniach umownych, naruszające interes jednej ze stron stosunku prawnego, mogą być rzetelnie stwierdzone jedynie w odniesieniu do konkretnej umowy kredytowej poprzez jej indywidualną ocenę. Podobnie ryzykowne jest arbitralne przyjmowanie w uzasadnieniu do projektu ustawy, że praktyki banków były nieuczciwe czy też miały charakter nieuczciwych praktyk rynkowych w odniesieniu do ogółu sytuacji. Dla dokonania takiej oceny niezbędne jest zbadanie konkretnej sprawy (umowy) wraz z uwzględnieniem całości jej uwarunkowań ${ }^{39}$.

Tytułem przykładu warto raz jeszcze przytoczyć wyrok Sądu Okręgowego w Szczecinie, który w zaistniałym stanie faktycznym wskazał, iż

[k]ursy publikowane przez NBP nie odbiegają jednak w sposób istotny od kursów stosowanych przez pozwanego, a przynajmniej nie w takim stopniu, żeby można było uznać, że w okresie przed 26 sierpnia $2011 \mathrm{r}$. doszło do rażącego naruszenia interesów powoda w rozumieniu art. $385^{1} \S 1$ k.c. na skutek stosowania przez pozwanego własnej Tabeli kursowej. Ponadto konkretne postanowienia umowy należy oceniać w całym jej kontekście, który wskazuje, że ekwiwalentem ryzyka związanego ze zmienną ceną franka szwajcarskiego było niższe oprocentowanie kredytu w relacji do typowych kredytów złotówkowych ${ }^{40}$.

37 Wyrok Sądu Okręgowego w Szczecinie z dnia 24 lutego 2016 roku.

38 A. Kawulski, op. cit., s. 345.

39 Komisja Nadzoru Finansowego, Opinia z dnia 7 października 2016 r. (DPP/WOP1/024/44/7 /16/MS) do prezydenckiego projektu ustawy o zasadach zwrotu należności wynikajacych z umów kredytu i pożyczki, druk sejmowy nr 811 Sejmu RP VIII kadencji, http://www.sejm.gov.pl/Sejm8.nsf/ druk.xsp?documentId=5AAC73C98996A266C125804B0048770F (dostęp: 8.11.2017).

40 Wyrok Sądu Okręgowego w Szczecinie z dnia 24 lutego 2016 roku. 


\section{Dopuszczalność klauzul walutowych w świetle art. $358^{1} \S 2$ Kodeksu cywilnego}

Możliwość zamieszczenia w umowie kredytu klauzuli waloryzacyjnej w sposób jednoznaczny dopuszcza art. $358^{1} \S 2$ Kodeksu cywilnego, który stanowi, iż strony mogą zastrzec w umowie, że wysokość świadczenia pieniężnego zostanie ustalona według innego niż pieniądz miernika wartości. Swobodę kształtowania umownych klauzul waloryzacyjnych wyznacza zaś art. $353^{1}$ Kodeksu cywilnego ${ }^{41}$.

Jednocześnie zostały podniesione głosy podważające dopuszczalność waloryzacji umownej na podstawie art. $358^{1} \S 5$ k.c., w wypadku gdy wysokość świadczenia określa bezwzględnie wiążący przepis ustawy. Tym wiążącym przepisem określającym wysokość świadczenia, który miałby rzekomo wykluczać możliwość zawarcia w umowie kredytu klauzuli walutowej, jest art. 69 ust. 1 Prawa bankowego ${ }^{42}$. W doktrynie wyrażono pogląd, iż

pomiędzy przepisami art. 69 PrBank oraz art. $358^{1} \S 2 \mathrm{KC}$ nie zachodzi zależność lex specialis-lex generalis. Przepis art. 69 PrBank nie może być traktowany jako przepis szczególny wobec art. $358^{1}$ $\S 2 \mathrm{KC}$, odmienny jest bowiem przedmiot regulacji wskazanych wyżej przepisów ${ }^{43}$.

W kwestii dopuszczalności konstrukcji kredytu indeksowanego (waloryzowanego) z perspektywy właśnie art. 69 Prawa bankowego wypowiedział się również przywołany już Sąd Najwyższy, w wyroku z dnia 22 stycznia 2016 roku wskazując, iż

„umowa kredytu indeksowanego” mieści się, oczywiście, w konstrukcji ogólnej umowy kredytu bankowego i stanowi jej możliwy wariant (art. $353^{1}$ k.c. w zw. z art. 69 prawa bankowego). Nie byłoby zatem podstaw do twierdzenia (i tak też nie twierdzi pozwany Bank), że w obrocie prawnym doszło do wykształcenia się jakiegoś odrębnego, oryginalnego typu umowy bankowej, powiązanej w sposób szczególny z kursem złotego do walut obcych w chwili wydania i zwrotu sumy kredytowej i tym samym — zakładającej szczególny sposób określania wysokości zadłużenia kredytobiorcy w stosunku kredytowym ${ }^{44}$.

Tłumacząc istotę umowy kredytu indeksowanego, Sąd Najwyższy stwierdził, że

Bank wydaje (udostępnia) kredytobiorcy określoną sumę kredytową w złotych, przy czym jej wysokość jest określana (indeksowana) według kursu danej waluty (np. euro) w dniu wydania (indeksowanie do waluty obcej po cenie kupna). Ustalenie takie następuje też w celu określenia wysokości

41 Szerzej zob. Kodeks cywilny. Komentarz, t. 3a. Zobowiazania. Czesść ogólna, red. K. Osajda, Warszawa 2017, Legalis.

42 Szerzej zob. Analiza prawna wybranych postanowień umownych stosowanych przez banki w umowach kredytów indeksowanych do waluty obcej lub denominowanych $w$ walucie obcej zawieranych z konsumentami. Raport Rzecznika Finansowego, Warszawa 2016, https://rf.gov.pl/ sprawybiezace/Raport_Rzecznika_Finansowego_Klauzule_niedozwolone_w_umowach_kredytow walutowych 22351 (dostęp: 8.11.2017).

${ }_{43}$ Z. Ofiarski, Z. Kuniewicz, op. cit., s. 256-268.

44 Wyrok Sądu Najwyższego z dnia 22 stycznia 2016 roku, I CSK 1049/14, LEX nr 2008735. 
rat kredytowych, do których kredytobiorca będzie zobowiązany w okresie trwania stosunku kredytowego. W dniu płatności konkretnych rat rata taka jest przeliczana zgodnie z umową na złote stosownie do kursu danej waluty (np. euro), tj. po kursie jej sprzedaży kontrahentowi banku ${ }^{45}$.

\section{W dalszej części Sąd Najwyższy zauważył, że}

[w] zakresie ,umowy kredytu indeksowanego” także dochodzi do wydania (udostępnienia, wypłaty) sumy kredytu kredytobiorcy i zwrotu wykorzystanej sumy kredytu z reguły w ratach kredytowych w dłuższym odcinku czasowym. Dla kredytobiorcy istotne znaczenie ma z reguły wysokość rat spłacanych w poszczególnych okresach ich spłat. Kredytobiorca zwraca kredytodawcy wykorzystaną sumę kredytu, przy czym w związku z kursem waluty obcej suma ta może być wyższa odpowiednio do relacji do waluty obcej. Suma wykorzystana w dniu wykonywania umowy kredytu hipotecznego może mieć bowiem inną wartość rynkową w wyniku indeksacji walutowej. Innymi słowy, kredytobiorca może być zobowiązany do zwrotu bankowi sumy pierwotnie wykorzystanego kredytu (w chwili wykonania umowy przez bank), ale taka wykorzystana suma (w całości lub części) może mieć inną (wyższą) wartość rynkową w okresie spłaty kredytu ${ }^{46}$.

Istotną konkluzją, którą odnotował Sąd Najwyższy w omawianym wyroku i którą należy odrębnie podkreślić, jest jednak wskazanie, że

[w] takiej sytuacji nie można twierdzić, że klauzula regulująca tzw. spread walutowy [...] „określa główne świadczenia stron" umowy kredytu bankowego (indeksowanego) w rozumieniu art. $385^{1}$ $\S 2$ zdanie drugie KC. De facto odnosi się ona bowiem bezpośrednio nie do samych elementów przedmiotowo istotnych umowy kredytu bankowego, tj. nie do oddania i zwrotu podstawowej sumy kredytowej. Kształtuje jedynie dodatkowy, zawarty we wzorcu umownym, mechanizm indeksacyjny wspomnianych głównych świadczeń stron stosunku kredytowego, tj. sposób określania rynkowej wartości wydanej i wykorzystywanej sumy kredytu w złotych w relacji do walut obcych ${ }^{47}$.

Sąd Najwyższy oparł swoje rozstrzygnięcie na zasadniczej funkcji walutowej indeksacji w umowie kredytu bankowego, jaką jest ustalenie i utrzymywanie wartości świadczenia w czasie (waloryzacyjny cel indeksacji). Klauzula przewidująca tak zwany spread walutowy tworzy wspomniany mechanizm, mający na celu realizację funkcji waloryzacyjnej w związku z indeksacją kredytu hipotecznego. Nie przesądza natomiast samej struktury, istoty i sekwencji świadczeń stron w ramach umowy kredytu bankowego (indeksowanego). Sąd Najwyższy powołał się przy tym na wyrok z dnia 2 lutego 2015 roku $^{48}$, zgodnie z którym umowna klauzula waloryzacyjna nie jest objęta wyłączeniem zawartym w art. $385^{1} \S 1$ zdanie drugie Kodeksu cywilnego, albowiem nie określa bezpośrednio świadczenia głównego, a wprowadza jedynie umowny reżim jego podwyższenia. W konkluzji Sąd Najwyższy trafnie stwierdził więc, iż

\section{Ibidem. \\ 46 Ibidem. \\ 47 Ibidem.}

48 Wyrok Sądu Najwyższego z dnia 2 kwietnia 2015 roku, I CSK 257/14, http://www.sn.pl/ sites/orzecznictwo/Orzeczenia3/I\%20CSK\%20257-14-1.pdf (dostęp: 18.07.2018). 
postanowienia bankowego wzorca umownego, zawierającego uprawnienie banku do przeliczania sumy wykorzystanego przez kredytobiorcę kredytu do waluty obcej (klauzula tzw. spreadu walutowego), nie dotyczą głównych świadczeń stron w rozumieniu art. $385^{1} \S 1$ zdanie drugie $\mathrm{KC}^{49}$.

W doktrynie wskazuje się ponadto, że uzależnienie wysokości kredytu od kursu waluty obcej jest rzekomo niedopuszczalne, dlatego że funkcję waloryzacyjną kredytu pełnią odsetki naliczane według zmiennej stopy procentowej. Na tej podstawie formułowany jest błędny pogląd, że kredyt indeksowany przewiduje „podwójną waloryzację”, co ma być niedopuszczalne. Po pierwsze, już w wyroku z dnia 4 listopada 2011 roku Sąd Najwyższy wyjaśnił, że

odsetki od udzielonego kredytu bankowego [...] stanowią bowiem, z jednej strony, cenę płaconą przez kredytobiorcę za korzystanie $\mathrm{z}$ oddanych mu do dyspozycji środków finansowych banku, z drugiej zaś strony - wynagrodzenie pobierane przez bank za udostępnienie kredytobiorcy tych środków ${ }^{50}$.

Po drugie, nawet gdyby przyjąć, iż dominującą funkcją odsetek jest waloryzacja świadczenia (co byłoby oczywiście błędne), to i tak w ramach kredytu indeksowanego nie dochodziło do ,podwójnej waloryzacji”. Przeliczenie na walutę obcą umówionej kwoty kredytu indeksowanego następuje, zgodnie z treścią umowy, w momencie jego uruchomienia. Od tej chwili wysokość rat kapitałowo-odsetkowych wyrażona jest w walucie obcej, wysokość nominalna rat wyrażona jest we franku szwajcarskim. Jest to również początkowy moment naliczania odsetek. Nie dochodzi zatem to jednoczesnej ,waloryzacji” i naliczania odsetek, gdyż wysokość rat kredytu wyrażona jest w CHF, a przeliczenie rat na PLN następuje w łącznie w sytuacji, gdy kredytobiorca decyduje się spłacać kredyt w walucie krajowej (przeliczanie rat z CHF na PLN nie pełni zatem funkcji waloryzacyjnej $)^{51}$.

Obecnie podnoszone są również wątpliwości, czy kredyty „denominowane” lub indeksowane do kursu waluty obcej są kredytami w walucie polskiej ${ }^{52}$. Jak się wydaje, kwestia nazewnictwa jest rzeczą wtórną - o tym, czy dany kredyt jest kredytem w walucie polskiej, czy w walucie obcej, decyduje bowiem treść konkretnej umowy kredytu ${ }^{53}$. Takie stanowisko wyraził także Wojewódzki Sąd Administracyjny w Gdańsku w wyroku z dnia 3 czerwca 2008 roku, który stwierdził, iż „o tym, czy mamy do czynienia z kredytem walutowym, czy też z kredytem

49 Ibidem.

50 Wyrok Sądu Najwyższego z dnia 4 listopada 2011 roku, I CSK 46/11, LEX nr 1102253.

51 Stanowisko Związku Banków Polskich z dnia 16 czerwca 2016 r. do Raportu Rzecznika Finansowego, Analiza prawna wybranych postanowień umownych stosowanych przez banki w umowach kredytów indeksowanych do waluty obcej lub denominowanych $w$ walucie obcej zawieranych z konsumentami, https://zbp.pl/public/repozytorium/archiwum/uwagi_do_RF.pdf (dostęp: 8.11.2017).

52 Zob. J. Molis, [w:] Prawo bankowe. Komentarz, red. F. Zoll, LEX 2005, s. 184; T. Czech, Sptata kredytu udzielonego $w$ walucie obcej..., s. 64-65.

53 A. Kawulski, op. cit., s. 347. 
denominowanym, rozstrzyga treść umowy, nie należy więc kierować się wyłącznie użytą w umowie nazwą kredytu" 54 .

W kontekście dopuszczalności zaciągania zobowiązania w walucie obcej $\mathrm{z}$ równoczesnym zastrzeżeniem, że wypłata i spłata będzie dokonywana w pieniądzu, Sąd Najwyższy wypowiedział się w wyroku z dnia 14 lipca 2017 roku:

Sąd Najwyższy wyjaśniał już, iż dopuszczalne jest zaciągnięcie zobowiązania w walucie obcej z równoczesnym zastrzeżeniem, że wypłata i spłata kredytu (pożyczki) będzie dokonywana w pieniądzu krajowym; zastrzeżenie takie dotyczy wyłącznie sposobu wykonania zobowiązania, przez co nie powoduje zmiany waluty wierzytelności ${ }^{55}$. Sąd Apelacyjny uznał, że sytuacja taka miała miejsce również w okolicznościach niniejszej sprawy, co opiera się na niepodważonej przez skarżących wykładni Umowy (brak zarzutu naruszenia art. 65 § 1 lub 2 k.c.). Wbrew zarzutowi skargi kasacyjnej stanowisko to jest trafne, ponieważ respektuje należycie wolę stron. Jej wyrazem jest nie tylko określenie w walucie obcej kwoty pożyczki i kwot podlegających zwrotowi, ale także inne postanowienia umowy. Należy uwzględnić, że we frankach szwajcarskich wyrażono także kwotę prowizji (§ 3 ust. 1 pkt 1 Umowy), wysokości hipoteki umownej (§ 4 pkt 1) oraz kwotę, do której Pożyczkobiorcy poddali się egzekucji (§ 22 ust. 1). Z Umowy wynika również, że zmienne oprocentowanie pożyczki miało być obliczane na podstawie wskaźnika LIBOR 3M (§ 5 ust. 1 i 3), właściwego dla franków szwajcarskich. Konsekwentnie wyrażona wola stron co do określenia kwoty „pożyczki” w walucie obcej powinna być respektowania także w odniesieniu do kwestii wprost w Umowie nieuregulowanych, a tezy tej nie podważa stwierdzenie, że określony przez strony mechanizm miał w istocie charakter waloryzacyjny. Uznając, że przedmiotem zobowiązania wynikającego z Umowy jest suma pieniężna wyrażona we frankach szwajcarskich, Sąd Apelacyjny nie naruszył art. 353 k.c. ${ }^{56}$

Sąd Najwyższy stwierdza dalej, iż ,[p]rzesądza to także o bezzasadności zarzutów naruszenia art. $358 \S 1$ i 2 k.c. w zakresie, w jakim oparte są one na tezie, że przedmiotem zobowiązania wynikającego z Umowy była suma pieniężna wyrażona w złotych polskich" 57 .

\section{Dopuszczalność klauzul walutowych w orzecznictwie Trybunału Sprawiedliwości UE}

Kwestia dopuszczalności traktowania kredytu walutowego jako stanowiącego instrument finansowy została poddana pod ocenę Trybunału Sprawiedliwości (UE), który w wyroku z dnia 3 grudnia 2015 roku w sposób jednoznaczny i bezsprzeczny uznał, iż kredyty denominowane nie stanowią instrumentu finansowego.

[...] art. 4 ust. 1 pkt 2 dyrektywy 2004/39 należy interpretować w ten sposób, że z zastrzeżeniem weryfikacji dokonanej przez sąd odsyłający nie stanowią usługi lub działalności inwestycyjnej w rozumieniu tego przepisu niektóre transakcje wymiany, dokonywane przez instytucję kredytową

54 Wyrok Wojewódzkiego Sądu Administracyjnego w Gdańsku z dnia 3 czerwca 2008 roku, I SA/Gd 174/08, LEX nr 394567.

55 Szerzej zob. Wyrok Sądu Najwyższego z dnia 25 marca 2011 roku, IV CSK 377/10, niepubl.; Wyrok Sądu Najwyższego z dnia 29 kwietnia 2015 roku, V CSK 445/14, niepubl.

56 Wyrok Sądu Najwyższego z dnia 14 lipca 2017 roku, II CSK 803/16, LEX nr 2369626.

57 Ibidem. 
na podstawie postanowień umowy kredytu denominowanego w walucie obcej, takiej jak umowa w postępowaniu głównym, polegające na określeniu kwoty kredytu na podstawie kursu kupna waluty mającego zastosowanie przy uruchomieniu środków oraz ustaleniu wysokości rat na podstawie kursu sprzedaży wspomnianej waluty mającego zastosowanie przy obliczaniu każdej raty ${ }^{58}$.

Jak wskazał Rzecznik Generalny Trybunału Sprawiedliwości UE,

warto przypomnieć podstawowe pojęcia prawa zobowiązań pieniężnych, a mianowicie „,walutę rachunku” oznaczającą miarę zobowiązania i „walutę płatności” oznaczającą sposób wykonania zobowiązania. [...] Korzystanie z klauzuli walutowej oznacza, że dłużnik zaciąga zobowiązanie do zapłaty nieokreślonej, lecz możliwej do określenia kwoty. Mamy jednakże do czynienia ze zobowiązaniem pieniężnym, które może zostać wykonane poprzez zapłatę właściwej kwoty w walucie płatności [...] sytuacja faktyczna w niniejszej sprawie wydaje się dotyczyć kredytu udzielonego przez bank konsumentowi w sytuacji, gdy walutą rachunku jest zgodnie z umową frank szwajcarski, którego wartość określa kapitał kredytu i raty, podczas gdy walutą płatności jest forint węgierski ${ }^{59}$.

\section{Ponadto Rzecznik Generalny TSUE wskazał, że:}

[w] uzgodnieniach dotyczących waluty, zawartych w umowie kredytu będącej przedmiotem postępowania głównego, wykonanie zobowiązania pieniężnego, określonego we frankach szwajcarskich, miało mieć miejsce $\mathrm{w}$ forintach węgierskich, po kursie $\mathrm{z}$ dnia zwrotu kredytu lub spłaty poszczególnych rat. To zakotwiczenie w rzeczywistym kursie franka szwajcarskiego pozbawia umowę charakteru kontraktu terminowego. Dzieje się tak dlatego, że część umowy, która miałaby stanowić kontrakt terminowy, nie przedstawia oddzielnej wartości prawnej lub ekonomicznej w stosunku do samej umowy kredytu. Jak słusznie zauważył rząd niemiecki, w istocie wymaga ona realizacji w walucie krajowej zobowiązania denominowanego w walucie obcej, lecz po aktualnym kursie w dniu płatności, zatem nie powoduje istotnej różnicy w odniesieniu do klasycznego kredytu w walucie obcej ${ }^{60}$.

Znamienny jest również wyrok Trybunału Sprawiedliwości UE z dnia 20 września 2017 roku w sprawie C-186/16, Ruxandra Paula Andriciuc i inni przeciwko Banca Românească $S A^{61}$, która dotyczyła umów kredytów hipotecznych denominowanych w CHF zawartych w latach 2004-2007. W toku postępowania przed TSUE analizowano pytania prejudycjalne zadane przez sąd rumuński, dotyczące interpretacji przepisów Dyrektywy Rady 93/13/EWG z dnia 5 kwietnia 1993 roku w sprawie nieuczciwych warunków w umowach konsumenckich.

Trybunał Sprawiedliwości stwierdził, iż art. 4 ust. 2 wskazanej dyrektywy należy interpretować w ten sposób, że pojęcie „głównego przedmiotu umowy" w rozumieniu tego przepisu obejmuje warunek umowny, taki jak ten rozpatrywany w postępowaniu głównym, ujęty w umowie o kredyt denominowany w walucie obcej, który nie był indywidualnie negocjowany i na mocy którego kredyt

58 Wyrok Trybunału Sprawiedliwości z dnia 3 grudnia 2015 roku w sprawie C-312/14, http:// eur-lex.europa.eu/legal-content/PL/TXT/HTML/?uri=CELEX:62014CJ0312\&from=PL (dostęp: 8.11.2017).

59 Opinia Rzecznika Generalnego z dnia 17 września 2015 roku (C-312/14), http://curia.europa.eu/juris/document/document.jsf;jsessionid=9ea7d2dc30d5fd53854487f744619589c468ca8 ce114.e34KaxiLc3qMb40Rch0SaxuSchj0?text=\&docid=167901\&pageIndex=0\&doclang=PL\&mo $\mathrm{de}=1 \mathrm{st} \& \operatorname{dir}=\& o c c=$ first\&part $=1 \& \mathrm{cid}=586521 \#$ Footnote 20 (dostęp: 8.11.2017).

60 Ibidem.

$61 \mathrm{http} / /$ curia.europa.eu/juris/liste.jsf?num=C-186/16 (dostęp: 8.11.2017). 
należy spłacić w tej samej walucie obcej co waluta, w której został on zaciągnięty, w wypadku gdy warunek ten określa podstawowe świadczenie charakteryzujące tę umowę. W konsekwencji warunku tego nie można uznać za nieuczciwy, o ile został on wyrażony prostym i zrozumiałym językiem.

Odnosząc się do określonego w art. 4 ust. 2 dyrektywy 93/13/EWG wymogu wyrażenia warunku umowy prostym i zrozumiałym językiem, Trybunał orzekł, że należy interpretować go w ten sposób, że w przypadku umów kredytowych instytucje finansowe muszą zapewnić kredytobiorcom informacje wystarczające do podjęcia przez nich świadomych i rozważnych decyzji. W tym względzie wymóg ów oznacza, że warunek dotyczący spłaty kredytu w tej samej walucie obcej co waluta, w której kredyt został zaciągnięty, musi zostać zrozumiany przez konsumenta zarówno w aspekcie formalnym i gramatycznym, jak i w odniesieniu do jego konkretnego zakresu, tak aby właściwie poinformowany oraz dostatecznie uważny i rozsądny przeciętny konsument mógł nie tylko dowiedzieć się o możliwości wzrostu lub spadku wartości waluty obcej, w której kredyt został zaciągnięty, lecz także oszacować - potencjalnie istotne - konsekwencje ekonomiczne takiego warunku dla swoich zobowiązań finansowych. Dokonanie niezbędnych ustaleń w tym zakresie należy do sądu krajowego.

W kontekście zaś wątpliwości co do momentu miarodajnego dla oceny nieuczciwego charakteru danego warunku umownego Trybunał wskazał, iż art. 3 ust. 1 dyrektywy 93/13/EWG należy interpretować w ten sposób, że oceny nieuczciwego charakteru warunku umownego należy dokonywać w odniesieniu do momentu zawarcia danej umowy, z uwzględnieniem ogółu okoliczności, które mogły być znane przedsiębiorcy w owym momencie i mogły mieć wpływ na późniejsze jej wykonanie. Do sądu odsyłającego należy ocena, w świetle ogółu okoliczności faktycznych sprawy w postępowaniu głównym i z uwzględnieniem między innymi fachowej wiedzy przedsiębiorcy, w tym przypadku banku, w zakresie ewentualnych wahań kursów wymiany i ryzyka wiążących się z zaciągnięciem kredytu w walucie obcej, istnienia ewentualnej nierównowagi w rozumieniu rzeczonego przepisu.

\section{Udzielanie kredytów denominowanych lub indeksowanych do waluty obcej w świetle wybranych rekomendacji Komisji Nadzoru Finansowego}

Udzielenie kredytu w walucie obcej wiąże się z szeregiem obowiązków informacyjnych po stronie kredytodawców. Komisja Nadzoru Bankowego w Rekomendacji $S$ z 2006 roku $^{62}$, a później Komisja Nadzoru Finansowego w Rekomenda-

${ }^{62}$ Komisja Nadzoru Bankowego, op. cit. 
cji $S$ (II) z 2008 roku $^{63}$, wydanych na podstawie art. 137 pkt 5 ustawy Prawo bankowe, rekomendowała, aby banki w pierwszej kolejności oferowały klientom kredyty, pożyczki lub inne produkty w złotych. Ponadto możliwość banku do złożenia klientowi oferty kredytu, pożyczki lub innego produktu w walucie obcej lub indeksowanego do waluty obcej uzależniona została od uprzedniego uzyskania od klienta pisemnego oświadczenia potwierdzającego, że dokonał on wyboru oferty w walucie obcej lub indeksowanej do waluty obcej, mając pełną świadomość ryzyka walutowego związanego z kredytami, pożyczkami i innymi produktami zaciąganymi w walucie obcej lub indeksowanymi do waluty obcej oraz wpływu spreadu walutowego na wysokość udostępnionego kredytu i poziom obciążenia jego spłatą (rekomendacja 19 pkt 5.1.7). Przywołana Rekomendacja $S$ (II) obligowała banki również do posiadania sporządzonych w formie pisemnej procedur wewnętrznych określających sposób i zakres informowania każdego klienta zaciągającego kredyt lub pożyczkę w walucie obcej lub indeksowane do tej waluty o związanym z tym ryzyku i jego konsekwencjach oraz wpływie spreadu walutowego na wielkość udostępnionego kredytu i poziom obciążenia jego spłatą. Wszystkie pytania i wątpliwości w tym zakresie powinny zostać wyjaśnione klientowi przez odpowiednio wyszkolonego pracownika, posiadającego niezbędną wiedzę na temat zagrożeń związanych z ryzykiem walutowym ekspozycji kredytowych zabezpieczonych hipotecznie (rekomendacja 19 pkt 5.1.8).

Ponadto rekomendacja 5.2.4, która obowiązywała od 1 lipca 2009 do 25 lipca 2011 roku, umożliwiła klientowi (na jego wniosek) spłatę rat w walucie indeksacyjnej przy kredycie indeksowanym kursem waluty obcej. Oznacza to, że wiele banków jeszcze przed wejściem w życie ustawy antyspreadowej stosowała zmienione wzorce umów, w których zawarte były klauzule w zakresie umożliwienia kredytobiorcy spłaty oraz wypłaty kredytu walutowego w walucie obcej tożsame z tymi, które wprowadziła ustawa antyspreadowa. W wypadku przyznania kredytobiorcy takiego prawa na mocy umowy kredytobiorca miał możliwość faktycznie nie korzystać ze spreadu stosowanego przez bank i jego sytuacja stawała się analogiczna do sytuacji kredytobiorców po dniu wejścia w życie ustawy antyspreadowej.

Rekomendacja $S$ Komisji Nadzoru Finansowego dotycząca dobrych praktyk w zakresie zarządzania ekspozycjami kredytowymi zabezpieczonymi hipotecznie (rekomendacja $6^{64}$ ) z 2013 roku rozszerzyła wymogi dotyczące udzielania walutowych kredytów hipotecznych, wskazując, iż oprócz należytej informacji o ryzyku walutowym kredytobiorca w celu uzyskania kredytu walutowego musi uzyskiwać dochody w danej walucie kredytu:

63 Komisja Nadzoru Finansowego, Rekomendacja S (II) dotyczaca dobrych praktyk w zakresie ekspozycji kredytowych zabezpieczonych hipotecznie, Warszawa 2008, https://www.knf.gov.pl/dla_ryn$\mathrm{ku} /$ regulacje_i_praktyka/rekomendacje_i_wytyczne/rekomendacje_dla_bankow?articleId $=857 \overline{6} \& \mathrm{p}$ id=18 (dostęp: 21.11.2017).

64 KNF oczekiwała, że Rekomendacja $S$ w zakresie rekomendacji 6 zostanie wprowadzona przez banki nie później niż do 1 lipca 2014 roku. 
Kredyty walutowe, indeksowane lub denominowane w walutach obcych powinny być produktem oferowanym wyłącznie klientom uzyskującym trwałe dochody w walucie kredytu, zapewniające regularną obsługę i spłatę kredytu. [...] W przypadku klientów (lub gospodarstw domowych) uzyskujących dochód w kilku walutach bank powinien zapewnić zgodność waluty kredytu z walutą, w której kredytobiorca (lub gospodarstwo domowe) uzyskuje najwyższe dochody z przyjmowanych do kalkulacji zdolności kredytowej, a w przypadku pozostałych walut bank powinien założyć ich deprecjację o $20 \%{ }^{65}$.

Na marginesie należy wskazać, iż w wyniku implementacji do polskiego porządku prawnego postanowienia Dyrektywy Parlamentu Europejskiego i Rady 2014/17/UE z dnia 4 lutego 2014 roku w sprawie konsumenckich umów o kredyt związanych z nieruchomościami mieszkalnymi i zmieniającej dyrektywy 2008/48/ WE i 2013/36/UE oraz rozporządzenie (UE) nr 1093/2010 ${ }^{66}$ Sejm RP uchwalił w dniu 23 marca 2017 roku ustawę o kredycie hipotecznym oraz o nadzorze nad pośrednikami kredytu hipotecznego i agentami (Dz.U. z 2017 r. poz. 819) ${ }^{67}$, która weszła w życie 22 lipca 2017 roku. W świetle przywołanej regulacji wprowadzone zostało ustawowe ograniczenie możliwości udzielania kredytów hipotecznych w walucie obcej w zależności od tego, czy konsument uzyskuje większość swoich dochodów lub posiada większość środków finansowych bądź innych aktywów wycenianych w walucie udzielenia kredytu lub walucie, do której kredyt jest indeksowany (art. 6 ust. 1). Należy bowiem założyć, że zamiarem racjonalnego ustawodawcy była prawidłowa implementacja art. 23 dyrektywy 2014/17/UE, który odwołuje się wprost do obowiązku zapewnienia przez państwa członkowskie odpowiednich ram regulacyjnych w stosunku do kredytu w walucie obcej, które będą obowiązywały w momencie zawierania umowy o ten kredyt. Wcześniej bowiem podobna regulacja funkcjonowała wyłącznie na gruncie Rekomendacji S Komisji Nadzoru Finansowego z 2013 roku, w której stwierdza się, iż bank powinien udzielać klientom detalicznym kredytów zabezpieczonych hipotecznie wyłącznie w walucie, w jakiej uzyskują oni dochód, także w wypadku klientów o wysokich dochodach (rekomendacja 6).

65 Komisja Nadzoru Finansowego, op. cit.

66 Dz.U. UE L 60 z dnia 28 lutego 2014 r., s. 34.

${ }^{67}$ Intencją projektodawcy — w odniesieniu do pierwotnej wersji projektu z dnia 25 maja 2016 roku, która początkowo zakładała możliwość udzielenia kredytów hipotecznych również firmom pożyczkowym - było ,wprowadzenie przepisu ustawowego, który będzie stosowany do wszystkich kredytodawców udzielających kredytów uregulowanych niniejszą ustawą. Biorąc pod uwagę, iż kredyty udzielane w walucie obcej są zdecydowanie bardziej ryzykowne dla konsumentów, którzy uzyskują swoje dochody tylko w złotych polskich, zdecydowano się na tego rodzaju przepis. W przypadku nieuregulowania tej kwestii w ustawie doszłoby do sytuacji, w której zgodnie z Rekomendacją S banki nie udzielałyby kredytów w walucie obcej konsumentom uzyskującym swoje dochody w złotych, natomiast pozostałe instytucje, które spełniałyby definicje kredytodawcy, mogłyby takich kredytów udzielać. Zasadne zatem wydaje się uregulowanie tej kwestii w ustawie również w celu stosowania jednolitych zasad do wszystkich kategorii kredytodawców" — uzasadnienie do druku sejmowego nr 1210 Sejmu RP VIII kadencji, http://www.sejm.gov.pl/Sejm8.nsf/ druk.xsp?d cumentId=989BC670C94550FFC12580AB004F8F4A (dostęp: 8.11.2017). 


\section{Dopuszczalność klauzul walutowych w świetle art. $58 \S 2$ Kodeksu cywilnego}

W zakresie zgodności umów kredytu hipotecznego denominowanych w walucie obcej z zasadami współżycia społecznego wypowiedział się Sąd Okręgowy w wyroku z dnia 18 kwietnia 2016 roku, w którym stwierdził, iż

zmienność kursów walut jest bowiem zjawiskiem powszechnie znanym, z którym każda osoba zawierająca umowę, w której wysokość świadczeń odniesiona jest do wartości waluty obcej, winna być obeznana. Nie sposób jest zatem twierdzić, iż z zawarciem tego rodzaju umowy wiąże się jakieś szczególne, niewidoczne dla zwykłego konsumenta ryzyko, przed ponoszeniem którego winien on być szczególnie chroniony. Ryzyko kursowe obciąża nadto obie strony w równym stopniu, w związku z czym nie można także stwierdzić, iż umowa taka ze swej natury zakłada pokrzywdzenie słabszej strony. Nie zawiera ona także żadnego elementu spekulacyjnego, który jest typowy dla finansowych instrumentów pochodnych. Na tej podstawie stwierdzić należało, iż brak jest podstaw do uznania umów kredytu hipotecznego denominowanego w walucie obcej za nieuczciwe, szczególnie niebezpieczne czy niemoralne, i przez to sprzeczne z zasadami współżycia społecznego. Konsekwentnie zatem brak jest także podstaw do uznania takich umów za nieważne zgodnie z art. $58 \S 2 \mathrm{KC}$. Działanie Państwa w zakresie ochrony konsumentów winno bowiem ograniczać się do ochrony ich przed działaniami podstępnymi bądź nieuczciwymi, nie mogą oni natomiast oczekiwać, iż państwo ochroni ich przed wszelkimi negatywnymi konsekwencjami podejmowanych przez nich decyzji gospodarczych ${ }^{68}$.

\section{Wnioski}

W świetle przedstawionych przepisów prawa oraz orzecznictwa wyraźnie widać dopuszczalność kredytów denominowanych lub indeksowanych do waluty innej niż polska i takie rozwiązanie stanowi element umowy kredytu i tym samym nie pozbawia takiej umowy charakteru umowy kredytu. Istnienie kredytów denominowanych lub indeksowanych do waluty obcej jednoznacznie przewiduje także Dyrektywa Parlamentu Europejskiego i Rady 2014/17/UE z dnia 4 lutego 2014 roku w sprawie konsumenckich umów o kredyt związanych z nieruchomościami mieszkalnymi.

Banki udzielające kredytów denominowanych lub indeksowanych do waluty obcej, zgodnie z przepisami obowiązującymi w czasie zawarcia umów kredytowych, miały prawo sądzić, że ukształtowany wówczas stosunek prawny będzie podlegał ochronie państwa, $w$ tym że przepisy prawa ingerujące $w$ ten stosunek nie zostaną zmienione w sposób istotnie niekorzystny dla którejś ze stron umowy. Podstawę poczucia bezpieczeństwa i możliwości układania swoich spraw w świetle obowiązujących przepisów regulujących prawa i obowiązki stron umowy kredytowej dawała stronom tej umowy konstytucyjna zasada zaufania do państwa i stanowionego przez nie prawa.

68 Wyrok Sądu Okręgowego w Warszawie z dnia 18 kwietnia 2016 roku, III C 275/15, LEX nr 2088294. 
Niepewność zarówno co do procedowanych, jak i zapowiadanych projektów ustaw dotyczących kredytów walutowych nie pozostaje bez wpływu na perspektywy dla akcji kredytowej. W Sejmie trwają obecnie prace nad czterema projektami zakładającymi ustawową ingerencję w stosunki umowne wynikające z zaciągnięcia kredytów walutowych ${ }^{69}$, w tym nad projektem przygotowanym przez Kancelarię Prezydenta RP, zakładającym zwrot części tak zwanych spreadów walutowych. Narodowy Bank Polski w Raporcie o stabilności systemu finansowego z czerwca 2017 roku wskazuje wyraźnie, iż

[k]oszty zwrotu tzw. spreadów obniżyłyby wyniki finansowe banków, a w przypadku niektórych z nich obciążyłyby bezpośrednio kapitały własne. Pozostałe projekty zakładające ustawowe przewalutowanie kredytów, szczególnie po kursie istotnie odbiegającym od rynkowego, mogłyby natomiast wiązać się z ryzykiem dla stabilności systemu finansowego i możliwości finansowania gospodarki. Na perspektywy akcji kredytowej może mieć wpływ realizacja rekomendacji Komitetu Stabilności Finansowej ${ }^{70}$.

W kontekście prezydenckiego projektu ustawy o zasadach zwrotu należności wynikających z umów kredytu i pożyczki (druk sejmowy nr 811 Sejmu RP VIII kadencji) Komisja Nadzoru Finansowego wskazała ponadto, iż

arbitralne przyjmowanie, że wszystkie umowy o kredyt denominowany/indeksowany obarczone były wadą w postaci ich niezgodności z prawem, czy też że zawierały postanowienia mające charakter nieuczciwych praktyk rynkowych, może być obarczone błędem. Nie uwzględnia ponadto faktu, że w czasie gdy były one zawierane, prawo nie zabraniało przewidywania w nich rozwiązań dotyczących spreadów walutowych (co nie oznacza oczywiście braku konieczności zbadania ich zgodności z prawem, przede wszystkim uregulowaniami chroniącymi interes konsumenta, jednakże ocena w tym zakresie powinna odbywać się z uwzględnieniem brzmienia poszczególnych umów) ${ }^{71}$.

Działania projektodawcy wkraczające w sferę działań inwestorów i naruszające swobodę obrotu gospodarczego nie są bowiem w sposób zupełny pozbawione limitacji. Pojawiające się rozwiązania w zakresie ingerencji w ukształtowane pod auspicjami powszechnie obowiązującego prawa stosunki prawne i ich prze-

69 Zob. poselski projekt ustawy o restrukturyzacji kredytów denominowanych lub indeksowanych do waluty innej niż waluta polska oraz o wprowadzeniu zakazu udzielania takich kredytów, druk sejmowy nr 729 Sejmu VIII kadencji, http://www.sejm.gov.pl/Sejm8.nsf/PrzebiegProc. xsp?nr=729 (dostęp: 18.07.2018); przedstawiony przez Prezydenta Rzeczpospolitej Polskiej projekt ustawy o zasadach zwrotu niektórych należności wynikających z umów kredytu i pożyczki, druk sejmowy nr 811 Sejmu VIII kadencji, http://www.sejm.gov.p1/Sejm8.nsf/PrzebiegProc.xsp?nr=811 (dostęp: 18.07.2018); oraz poselski projekt ustawy o szczególnych zasadach restrukturyzacji walutowych kredytów mieszkaniowych w związku ze zmianą kursu walut obcych do waluty polskiej, druk sejmowy nr 877 Sejmu VIII kadencji, http://www.sejm.gov.pl/Sejm8.nsf/PrzebiegProc. xsp?nr=877 (dostęp: 18.07.2018).

70 Narodowy Bank Polski, Raport o stabilności systemu finansowego, Warszawa 2017, https:// www.nbp.pl/systemfinansowy/rsf062017.pdf (dostęp: 8.11.2017).

71 Komisja Nadzoru Finansowego, Opinia do prezydenckiego projektu ustawy o zasadach zwrotu należności wynikających z umów kredytu i pożyczki, druk sejmowy nr 811 Sejmu RP VIII kadencji (DPP/WOP1/024/44/7/16/MS), s. 3, http://www.sejm.gov.pl/Sejm8.nsf/druk.xsp?docume ntId=5AAC73C98996A266C125804B0048770F (dostęp: 8.11.2017). 
widywane negatywne skutki dla inwestorów powinny podlegać szczegółowemu badaniu pod kątem potencjalnego naruszenia zawartych przez Polskę umów międzynarodowych, to jest umów o wzajemnym popieraniu i ochronie inwestycji (z ang. Bilateral Investment Treaties - BIT). W wypadku naruszenia postanowień BIT Polska może zostać narażona na odpowiedzialność odszkodowawczą. Bezsprzecznym pozostaje bowiem prawo inwestora do usprawiedliwionych oczekiwań działania z pewnym zaufaniem co do uwarunkowań prawnych prowadzonej działalności gospodarczej, wobec czego dokonywane zmiany prawa nie powinny mieć charakteru radykalnego, w szczególności w aspekcie ingerencji w rozliczone i zamknięte stosunki umowne.

\section{Bibliografia}

\section{Literatura}

Czech T., Charakter prawny rekomendacji Komisji Nadzoru Finansowego, „Przegląd Prawa Publicznego" 2009, nr 11.

Czech T., Sptata kredytu udzielonego w walucie obcej lub indeksowanego do waluty obcej, „Monitor Prawa Bankowego" 2011, nr 11.

Kawulski A., Prawo bankowe. Komentarz, Warszawa 2013.

Kodeks cywilny. Komentarz, t. 3a. Zobowiązania. Część ogólna, red. K. Osajda, Warszawa 2017.

Krzyżewski J.A., Rekomendacje nadzorcze — charakter prawny i zakres mocy obowiąującej, „Prawo Bankowe" 2000, nr 7-8.

Mazur L., Prawo bankowe. Komentarz, Warszawa 2008.

Ofiarski Z., Prawo bankowe. Komentarz, Warszawa 2013.

Ofiarski Z., Kuniewicz Z., Problem dopuszczalności przeksztatcenia kredytu denominowanego lub indeksowanego do waluty obcej w kredyt w walucie polskiej z uwagi na abuzywność klauzuli walutowej (uwagi na tle art. 69 PrBank do art. $385^{1} \xi 2 \mathrm{KC}$ ), [w:] Życie umowy konsumenckiej po uznaniu jej postanowienia za nieuczciwe na tle orzecznictwa Trybunału Sprawiedliwości, red. M. Romanowski, Warszawa 2017.

Paxford B., Kredyty i pożyczki pieniężne oraz zasady koncentracji zaangażowani, [w:] Prawo bankowe. Komentarz, red. H. Gronkiewicz-Waltz, Warszawa 2013.

Prawo bankowe. Komentarz, red. H. Gronkiewicz-Waltz, Warszawa 2013.

Prawo bankowe. Komentarz, red. G. Sikorski, Warszawa 2015.

Prawo bankowe. Komentarz, red. F. Zoll, LEX 2005.

Rutkowska E., Środki nadzoru bankowego, [w:] Prawo bankowe, red. E. Fojcik-Mastalska, Wroclaw 2009.

\section{Orzecznictwo}

Wyrok Sądu Apelacyjnego w Białymstoku z dnia 20 listopada 2012 roku, I ACa 499/12, LEX nr 1235971.

Wyrok Sądu Najwyższego z dnia 4 listopada 2011 roku, I CSK 46/11, LEX nr 1102253.

Wyrok Sądu Najwyższego z dnia 19 marca 2015 roku, IV CSK 362/14, LEX nr 1663827.

Wyrok Sądu Najwyższego z dnia 2 kwietnia 2015 roku, I CSK 257/14, http://www.sn.pl/sites/ orzecznictwo/Orzeczenia3/I\%20CSK\%20257-14-1.pdf.

Wyrok Sądu Najwyższego z dnia 22 stycznia 2016 roku, I CSK 1049/14, LEX nr 2008735. 
Wyrok Sądu Najwyższego z dnia 14 lipca 2017 roku, II CSK 803/16, LEX nr 2369626. Wyrok Sądu Okręgowego w Szczecinie z 24 lutego 2016 roku, I C 523/15, LEX nr 2244692. Wyrok Sądu Okręgowego w Warszawie z dnia 18 kwietnia 2016 roku, III C 275/15, LEX nr 2088294. Wyrok Trybunału Sprawiedliwości UE z dnia 3 grudnia 2015 roku w sprawie C-312/14, http://eur-lex.europa.eu/legalcontent/PL/TXT/HTML/?uri=CELEX:62014CJ0312\&from=PL.

Wyrok Trybunału Sprawiedliwości UE z dnia 20 września 2017 roku w sprawie C-186/16, http:// curia.europa.eu/juris/liste.jsf?num=C-186/16.

Wyrok Wojewódzkiego Sądu Administracyjnego w Gdańsku z dnia 3 czerwca 2008 roku, I SA/Gd 174/08, LEX nr 394567.

\section{Źródła internetowe}

Komisja Nadzoru Bankowego, Rekomendacja $S$ dotyczaca dobrych praktyk $w$ zakresie ekspozycji kredytowych zabezpieczonych hipotecznie, Warszawa 2006, https://www.knf. gov.pl/dla_rynku/regulacje_i_praktyka/rekomendacje_i_wytyczne/rekomendacje_dla_ bankow? articleId=8576\&p_id=18.

Komisja Nadzoru Finansowego, Opinia do prezydenckiego projektu ustawy o zasadach zwrotu należności wynikających z umów kredytu i pożyczki, druk sejmowy nr 811 Sejmu RP VIII kadencji (DPP/WOP1/024/44/7/16/MS), http://www.sejm.gov.pl/Sejm8.nsf/druk.xsp?documentId= 5AAC73C98996A266C125804B0048770F.

Komisja Nadzoru Finansowego, Przypomnienie publicznej dyskusji o kredytach walutowych, 10.03.2015, https://www.knf.gov.pl/knf/pl/komponenty/img/knf_130218_przypomnienie_ publicznej_dyskusji_CHF_40728.pdf.

Komisja Nadzoru Finansowego, Rekomendacja $S$ dotyczaca dobrych praktyk w zakresie zarzadzania ekspozycjami kredytowymi zabezpieczonymi hipotecznie, Warszawa 2013, https://www. knf.gov.pl/dla_rynku/regulacje_i_praktyka/rekomendacje_i_wytyczne/rekomendacje_dla_ bankow.

Komisja Nadzoru Finansowego, Rekomendacja S (II) dotyczaca dobrych praktyk $w$ zakresie ekspozycji kredytowych zabezpieczonych hipotecznie, Warszawa 2008, https://www.knf. gov.pl/dla_rynku/regulacje_i_praktyka/rekomendacje_i_wytyczne/rekomendacje_dla_ bankow?articleId=8576\&p_id=18.

Komisja Nadzoru Finansowego, Rekomendacja T dotyczaca dobrych praktyk $w$ zakresie zarzadzania ryzykiem detalicznych ekspozycji kredytowych, Warszawa 2010, https://www.knf. gov.pl/dla_rynku/regulacje_i_praktyka/rekomendacje_i_wytyczne/rekomendacje_dla_ bankow?articleId $=8576 \& \mathrm{p} \_\mathrm{id}=18$.

Komitet Stabilności Finansowej, Uchwała Nr 14/2017 Komitetu Stabilności Finansowej z dnia 13 stycznia 2017 r. w sprawie rekomendacji dotyczacej restrukturyzacji portfela kredytów mieszkaniowych $w$ walutach obcych, https://www.nbp.pl/nadzormakroostroznosciowy/podstawa/uchwala_ksfm_14_13-01-2017.pdf.

Komunikat prasowy Klubu Parlamentarnego Prawa i Sprawiedliwości dotyczący zalecenia Komisji Nadzoru Bankowego, http://old.pis.org.pl/article.php?id=4415.

Narodowy Bank Polski, Raport o stabilności systemu finansowego, https://www.nbp.pl/systemfinansowy/rsf062017.pdf.

Opinia Rzecznika Generalnego Niila Jääskinena przedstawiona w dniu 17 września 2015 r. Sprawa C-312/14 Banif Plus Bank Zrt. Przeciwko MártonLantos i Mártonné Lantos, http://curia.europa.eu/juris/document/document.jsf;jsessionid=9ea7d2dc30d5fd53854487f744619589c468ca 
8ce114.e34KaxiLc3qMb40Rch0SaxuSchj0?text=\&docid=167901\&pageIndex $=0 \&$ doclang $=P$ L\&mode $=1$ st\&dir $=\&$ occ $=$ first\&part $=1 \&$ cid $=586521$ \#Footnote 20 .

Prezes Urzędu Ochrony Konkurencji i Konsumenta, Odpowiedź z dnia 2 sierpnia 2006 r. na pismo Redaktora Naczelnego money.pl (DDK-076-251/06/KB), https:/www.google.pl/url?sa=t\&rct$=\mathrm{j} \& \mathrm{q}=\& \mathrm{esrc}=\mathrm{s} \&$ source $=$ web $\& \mathrm{~cd}=2 \& \mathrm{cad}=\mathrm{rja} \& u a c t=8 \& \mathrm{ved}=0$ ahUKEwijt4DPyc $\_$XAhUmJJ oKHeD8BfsQFggtMAE\&url=http\%3A\%2F\%2Fwww.money.pl\%2Fu\%2Ffile.php $\% 3$ Fid $\% 3$ D3477\&usg=AOvVaw1qj0KOdYLCwCK0qNKoS1yi.

Projekt ustawy o restrukturyzacji kredytów denominowanych lub indeksowanych do waluty innej niż waluta polska oraz o wprowadzeniu zakazu udzielania takich kredytów, druk sejmowy nr 729 Sejmu RP VIII kadencji, http://www.sejm.gov.pl/Sejm8.nsf/PrzebiegProc.xsp?nr=729.

Projekt ustawy o szczególnych zasadach restrukturyzacji walutowych kredytów mieszkaniowych w związku ze zmianą kursu walut obcych do waluty polskiej, druk sejmowy nr 877 Sejmu RP VIII kadencji, http://www.sejm.gov.pl/Sejm8.nsf/PrzebiegProc.xsp?nr=877.

Projekt ustawy o zasadach zwrotu niektórych należności wynikających z umów kredytu i pożyczki, druk sejmowy nr 811 Sejmu RP VIII kadencji, http://www.sejm.gov.pl/Sejm8.nsf/PrzebiegProc. $x$ sp? $\mathrm{nr}=811$.

Rzecznik Finansowy, Analiza prawna wybranych postanowień umownych stosowanych przez banki $w$ umowach kredytów indeksowanych do waluty obcej lub denominowanych $w$ walucie obcej zawieranych z konsumentami. Raport Rzecznika Finansowego, https://rf.gov.pl/sprawybiezace/Raport_Rzecznika_Finansowego_Klauzule_niedozwolone_w_umowach_kredytow walutowych_ 22351 .

Schweizerische Nationalbank, Press release: Swiss National Bank discontinues minimum exchange rate and lowers interest rate to $-0.75 \%, 15.01 .2015$, https://www.snb.ch/en $/ \mathrm{mmr} / \mathrm{reference/}$ pre_20150115/source/pre_20150115.en.pdf.

Urząd Komisji Nadzoru Finansowego, Ocena wpływu na sytuację sektora bankowego i polskiej gospodarki propozycji przewalutowania kredytów mieszkaniowych udzielonych w CHF na PLN wedlug kursu z dnia udzielenia kredytu, Warszawa 2013, https://www.knf.gov. $\mathrm{pl} /$ ?articleId $=56126 \& \mathrm{p} \_\mathrm{id}=18$.

Uzasadnienie do poselskiego projektu ustawy o zmianie ustaw dotyczących kredytu konsumenckiego, druk sejmowy nr 4350 Sejmu RP VI kadencji, http:/orka.sejm.gov.pl/proc6.nsf/opisy/4350.htm.

Uzasadnienie do poselskiego projektu ustawy o zmianie ustaw dotyczących kredytu konsumenckiego, druk sejmowy nr 4381 Sejmu RP VI kadencji, http://orka.sejm.gov.pl/proc6.nsf/opisy/4381.htm.

Uzasadnienie do poselskiego projektu ustawy o zmianie ustawy - Prawo bankowe, druk sejmowy nr 4413 Sejmu RP VI kadencji, http://orka.sejm.gov.pl/proc6.nsf/opisy/4413.htm.

Uzasadnienie do rządowego projektu ustawy o kredycie hipotecznym oraz o nadzorze nad pośrednikami kredytu hipotecznego i agentami, druk sejmowy nr 1210 Sejmu RP VIII kadencji, http:// www.sejm.gov.pl/Sejm8.nsf/druk.xsp?documentId=989BC670C94550FFC12580AB004F8F $4 \mathrm{~A}$.

Związek Banków Polskich, Biała księga kredytów frankowych w Polsce, Warszawa 2015, https:// zbp.pl/public/repozytorium/wydarzenia/images/marzec_2015/BIAA_OST_2_4_marca_2015_small_pdf.

Związek Banków Polskich, Stanowisko Związku Banków Polskich do opracowania Rzecznika Finansowego pt. „,Analiza prawna wybranych postanowień umownych stosowanych przez banki $w$ umowach kredytów indeksowanych do waluty obcej lub denominowanych $w$ walucie obcej zawieranych z konsumentami", Warszawa 2016, https://zbp.pl/public/repozytorium/archiwum/ uwagi_do_RF.pdf. 